\begin{tabular}{|c|c|c|}
\hline Beitr. Ent. & Keltern & ISSN 0005-805X \\
\hline $\mathbf{5 8}(2008) 2$ & S. $441-453$ & 15.11 .2008 \\
\hline
\end{tabular}

\title{
The Obakunea group in Tasmania, with description of Colonomyia tasmanica sp. n.
}

\section{(Diptera: Sciaroidea)}

With 5 figures

\section{Mathias Jaschhof and Catrin Jaschhof}

\section{Summary}

The Ohakunea group of genera (unplaced to any family of the Sciaroidea) is present in Tasmania with three species: Ohakunea australiensis Colless, which is newly recorded, Colonomyia albicaulis Colless, and Colonomyia tasmanica sp. $\mathrm{n}$. The new species, which appears to be endemic to Tasmania, is the closest relative of Colonomyia rakelae Hippa \& JAschHof from New Guinea. New arguments presented here support the hypothesis that the Australasian species of Colonomyia form a clade (= Colonomyia sensu stricto) distinct from the congeneric species in the Neotropical region. The complex structure of male and female terminalia of Colonomyia s. str. spp. possibly present an example of lock-and-key that is documented and discussed.

\section{Zusammenfassung}

Die Ohakunea-Gattungsgruppe, die keiner Familie innerhalb der Sciaroidea zugeordnet ist, hat drei Arten in Tasmanien: Ohakunea australiensis Colless, die erstmals von dort gemeldet wird, Colonomyia albicaulis Colless und Colonomyia tasmanica sp. n. Die neue Art, die offenbar in Tasmanien endemisch ist, ist nächstverwandt mit Colonomyia rakelae Hippa \& JasCHHOF von Neuguinea. Hier dargelegte neue Argumente unterstützen die Hypothese, dass die australasiatischen Colonomyia-Arten eine Abstammungsgemeinschaft (= Colonomyia sensu stricto) bilden, die von den kongenerischen Arten in der neotropischen Region gut unterschieden ist. Die komplexe Struktur des männlichen und weiblichen Genitalapparates von Colonomyia s. str. spp. wird dargestellt und dahingehend diskutiert, dass hier möglicherweise ein Beispiel für den Schlüssel-Schloss-Mechanismus vorliegt.

\section{Keywords}

Diptera, Sciaroidea, Ohakunea group, Colonomyia, new species, Tasmania

\section{Introduction}

Sciaroids of the Ohakunea group are small, dull-coloured gnats with the cryptic behaviour of dwellers of damp forests, mainly in the southern hemisphere. Their larvae have not yet been found, but are assumed to live as fungivorous saproxylics. Dipterist-systematists regard the Ohakunea group of genera as enigmatic. Its phylogenetic relationships to the other Sciaroidea are unresolved and even its monophyly is occasionally questioned (Hippa \& VILKAMAa 2005, 2006; Jaschnof 2006; Amorim \& Rindal 2007). The hypothesis advanced here is that of an 
ancient, little diversified clade, which we presume will be eventually given a rank equal to the traditionally recognized families of the Sciaroidea. As long as a robust phylogenetic hypothesis for the Sciaroidea is wanting, however, we consider the Ohakunea group to be unranked and unplaced within the family classification as currently accepted (e. g. SøLI et al. 2000).

Of the four genera and altogether 15 species of the Ohakunea group, two genera with one species each were hitherto known to occur in southeast Australia: Ohakunea australiensis Colless and Colonomyia albicaulis Colless, with the latter once recorded also in Tasmania (Colless 1963, Semmens et al. 1992, Jaschrof \& Hippa 2003, Hippa \& Jaschrof 2004, Amorim \& Rindal 2007). As a result of our recently begun studies of Tasmanian sciaroids we are in a position to report here on new findings: the first record in Tasmania of Ohakunea australiensis; the occurrence in abundance of Colonomyia albicaulis in Tasmania's south-west; and the presence of a new Colonomyia species, named here tasmanica, which we found sympatric with and even more abundant than albicaulis. The new material enables us to distinguish more definitely than before an Australasian lineage of Colonomyia (= Colonomyia sensu stricto) from a Neotropical lineage and characterize the genitalic structures of Colonomyia s. str. spp. in more detail.

\section{Material and methods}

Most of the specimens studied here were picked from Malaise samples, either unsorted or presorted to the level of Diptera, from the Tasmanian Forest Insect Collection (TFIC) in the care of Forestry Tasmania, Hobart. These samples were taken at Warra, which is one of the world's Long Term Ecological Research (LTER) Sites, straddling the Tasmanian Wilderness World Heritage area and neighbouring State forests. Trap sites were located in unmanaged forest (on specimen labels referred to as control or pre-logging areas), or forest disturbed from various silvicultural treatments (referred to as treatment areas and further specified where appropriate), both at Manuka Road; other traps were located in undisturbed forest along an altitudinal transect (100 to $1000 \mathrm{~m}$ a.s.l.) at Mt Weld (BASHFORD et al. 2001). While the invertebrate trapping program at Warra LTER Site is part of an ecological research effort, our own studies are purely taxonomic. Forests at Warra are mainly of the wet eucalypt forest type, which is the most widespread forest community in Tasmania and part of the southern cool temperate wet forest biome (WARRA POLICY Committee \& Research Management Group, without year; Brown et al. 2001). Under less frequent occurrence of fires wet eucalypt forest develops into what is commonly called mixed forest, which is old-growth eucalypts (at Warra stringybark Eucalyptus obliqua) emergent over a rainforest understorey (including myrtle Nothofagus cunninghamii) (e. g. JonEs et al. 1999). A few specimens were taken at Tasmanian localities other than Warra, including those visited by the Naturhistoriska Riksmuseet Stockholm (NHRS) entomological expedition in 2006. The holotype of Colonomyia tasmanica is deposited with the Australian Museum, Sydney (AMS); paratypes and voucher specimens, also of the other species treated here, are deposited with the AMS, TFIC, NHRS, and the Jaschhof collection in the Deutsches Entomologisches Institut, Müncheberg, Germany (DEIC).

The type-series of Colonomyia tasmanica, and a few specimens each of the other species were mounted on microscope slides in Canada balsam, after dehydration in $70 \%$ ethanol and overnight treatment in beechwood creosote. Head, antennae, legs, wings, abdomen, and terminalia of some specimens were detached and mounted under separate cover slips. To facilitate more detailed observation, the male terminalia of a few specimens were dissected by very fine insect pins between the aedeagus and sternite 10, i. e. into dorsal and ventral portions. Female terminalia 
were dissected between gonapophyses 9 and gonocoxites 8. Most of the specimens are kept in $70 \%$ ethanol.

Morphological terminology follows that by SøLI (1997) for Mycetophilidae, and by SINCLAIR (2000) for some terms related to the male terminalia. Drawings were made using an Olympus BX50 microscope in combination with the U-DA drawing unit.

\section{Genus Ohakunea TonNOIR \& EDWARDs, 1927}

Tonnoir \& Edwards 1927: 799, Freeman 1951: 28, Colless 1963: 303, Jaschhof \& Hippa 2003.

Four named species of the genus Ohakunea occur in the Australasian region (New Guinea, Australia, New Zealand) and one species in the southern Neotropical region. Additionally, we know of a presumably unnamed species, of which only females have been found so far, present in New Caledonia. Intrageneric relationships of Ohakunea were discussed by JAschноғ \& HippA (2003).

Previously overlooked, the tarsi of Ohakunea spp. bear setiform sensilla that are randomly distributed and perpendicular to the surface so that they stick out from the tarsal vestiture. They are presumably homologous to the sensilla described for Colonomyia spp., which however are arranged in-line and occur only on basitarsi (Hippa \& JaschHof 2004). The first antennal flagellomeres of Ohakunea spp. bear subbasally a few socketed setae (e. g. up to 8 in australiensis), which was not previously reported.

\section{Obakunea australiensis COLLESS, 1963}

Colless 1963: 304, JaschHof \& Hippa 2003: 29.

\section{Intraspecific variation:}

The antennae are longer in specimens from Tasmania than in those from the Australian mainland, in the male more so than in the female. Male fourth flagellomeres, described to be 5.5 times as long as wide for mainland specimens (Jaschiof \& Hippa 2003), are up to 7 times so in Tasmanian specimens.

\section{Distribution and phenology:}

This species is indigenous to Australia and was introduced to New Zealand. In Australia its mainland distribution is confined to the southeasternmost Queensland (unpublished data), New South Wales, and Victoria. In Tasmania it occurs as sparsely as elsewhere in its distributional range. At Warra eight different Malaise samples yielded each one specimen, altogether six males and two females. Findings are from January to April and October, all from an altitude of $100 \mathrm{~m}$ a.s.l., and from both unmanaged and treated forest areas.

Material studied (on slide):

Tasmania: 2 males, Warra LTER Site, Manuka Road, 13 Oct. 2002, R. BAshrord; 1 female, same site but 20 April 2004; 1 male, 1 female, same site but 1 March 2005; 1 male, same site but 1 April 2005.

Further material (in ethanol):

Tasmania: 1 male, Warra LTER Site, Manuka Road, 24 March 2000, R. BASHFord; 1 male, same site but 22 Jan. 2002. 


\section{Genus Colonomyia Colless, 1963}

Colless 1963: 305, Matile \& Duret 1994, Hippa \& Jaschhof 2004, Amorim \& Rindal 2007: 15.

This genus has an amphinotic distribution (Matile \& Duret 1994) with six species found in the Neotropical region and three species, including tasmanica sp. n., in the Australasian region. The Neotropical species, with the possible exception of obtusistyla Matile \& Duret, belong to a lineage distinct from the Australasian species (Hippa \& Jaschно 2004). The position of obtusistyla, with regressive adult morphology, is still obscure. The Australasian lineage (Colonomyia sensu stricto) is characterized as follows (Hippa \& JASCHноғ 2004, this paper): the setose portion of face is small; the microtrichia on postnotum are large and clustered in circular groups; the number of pale setiform sensilla on the basitarsi is small, i. e. not exceeding five; the apical portion of $\mathrm{CuA} 2$ is slightly sinuous; the male tergite 9 is two-lobed; the sperm sac is large, slightly sclerotized, and has a large pubescent bulge close to the primary gonopore; the male sternite 10 is subtriangular; and the female sternum 8 has laterally a sclerotized interior brace. One may expect that when the terminalia of the Neotropical species are studied to the same detail as done here, further differences will appear between the Neotropical and Australasian lineages. Moreover, one may anticipate the generic separation of these two lineages, which will require resolution of the position of obtusistyla.

The male terminalia of Colonomyia s. str. spp. are peculiar for the presence of the large, elaborate sperm sac with a tubular posterior extension, the endophallus (Fig. 2). This is not described for any of the Neotropical species, nor could we observe it in the specimens we have at hand of borea Hippa \& JaschHof, of an unnamed species near borea, and of magellanica Matile \& Duret. The sperm pump of Colonomyia s. str. (Fig. 1B) has a configuration similar to that in some basal Brachycera (cf. SinclaIr 2000: figs 20-23) and should function accordingly, i. e. by the ejaculatory apodeme, even though not particularly broad, compressing the sperm sac. The ejaculatory apodeme of Colonomyia s. str. bears three muscles (mI-mIII): mI leading from the apodeme base to the parameres; $\mathrm{mII}$ from the apodeme base to the ventrobasal rim of gonocoxites, and $\mathrm{mIII}$ from the longitudinal carina to the apical portions of the gonocoxal apodemes. Speciesspecific modifications of this pattern include: $\mathrm{mI}$ that in tasmanica has a fascicle leading to the basal portions of the gonocoxal apodemes, and mIII that in albicaulis has a fascicle inserted on the apex of the ejaculatory apodeme. It is likely that the "head-like extension of the ejaculatory apodeme" (Hippa \& JASCHHOF 2004) is completely or partially referable to the aedeagus, viz. its sclerotized apex.

Quite unusual for Sciaroidea, in Colonomyia s. str. the elaborate, highly flexible construction of the male copulatory organ has a counterpart in the female, which is composed of derivatives of the ninth segment. Of that segment, the tergite, largely internalized, and the gonapophyses form together a complex, expansive apparatus, which occupies the dorsal and posterior walls of the genital chamber. Rigid, sclerotized parts are interlinked through soft connective tissue, which form an apparently quite flexible structure supported by several muscles. In the two Australian species, albicaulis and tasmanica, of which this apparatus has been studied in some detail, its construction is definitely species-specific. One may assume that there is a tight mechanical fit between the male and female structures, but pairs in copula, which might furnish proof, have not yet been found. 


\section{Key to male Colonomyia in Australasia}

1 Gonocoxites with 1 longitudinal sclerotized rib along midline of basal portion (Fig. 1A); apex of ejaculatory apodeme spade-like (Fig. 1A) 2

Gonocoxites with 2 distant longitudinal sclerotized ribs; apex of ejaculatory apodeme with 2 pairs of slender processes albicaulis Colless (SE Australia including Tasmania)

2 Gonostylus with dorsomesal lobe (Fig. 2); parameres apically two-lobed, lateral lobe slender and apically serrate, mesal lobe wide and rounded (Fig. 2) .. tasmanica sp. n. (Tasmania) Gonostylus without dorsomesal lobe; parameres tusk-like and apically pointed rakelae Hippa \& JaschHof (New Guinea)

\section{Key to female Colonomyia in Australasia}

1 Tergite and gonapophyses of segment 9 strongly sclerotized, forming expansive, complex interior apparatus (Figs 4B, 5B); tergite 8 on posterior margin with 2 wide pubescent lobes (Fig. 4B) albicaulis Colless (SE Australia including Tasmania)

- $\quad$ Tergite and gonapophyses of segment 9 more weakly sclerotized (Figs 3A, 4A, 5A); tergum 8 posterior of its setose portion with large bare portion (Fig. 4A) 2

2 Tergum 8 on posterior margin with pubescent lobe mesally (Fig. 4A) tasmanica sp. n. (Tasmania) Tergum 8 without lobe on posterior margin ... rakelae Hippa \& Jaschноғ (New Guinea)

\section{Colonomyia tasmanica sp. $\mathbf{n}$.}

(Figs 1-3, 4A, 5A)

\section{Description:}

(for characters not mentioned here see the generic redescription by Hippa \& JASCHHOF 2004):

Male. Body length: 2.0-2.2 mm. Head: Postfrons setose. First antennal flagellomere subbasally with up to 4 socketed setae. Fourth flagellomere 5 times as long as wide. Apex of apical flagellomere with a few sensory spines. Setose portion of face small. Labrum non-setose.

\section{Thorax:}

Scutum with some sublateral setae larger than others. Microtrichia on postnotum large and clustered in groups of 5-6. Laterotergite non-setose. Legs: Anteroapical depression on fore tibia with numerous setae, the distalmost forming an irregular comb. Mid tibia with apical comb of 6-7 spine-like setae, hind tibia 10-11. Fore basitarsus proximally with no pale setiform sensilla, mid basitarsus with 1, hind basitarsus with 2-3. Wing: Rs traceable as very faint vein close to base of wing, or only by tracheae. M-stem and base of M-fork obliterated. Base of CuA1 very weak, either coalescing at one point with $\mathrm{CuA} 1$ and longitudinal vein, or joining longitudinal vein somewhat distal to that juncture. $\mathrm{CuA} 2$ sinuous apically, i. e. its apex directed distad. A2 present, albeit short. 


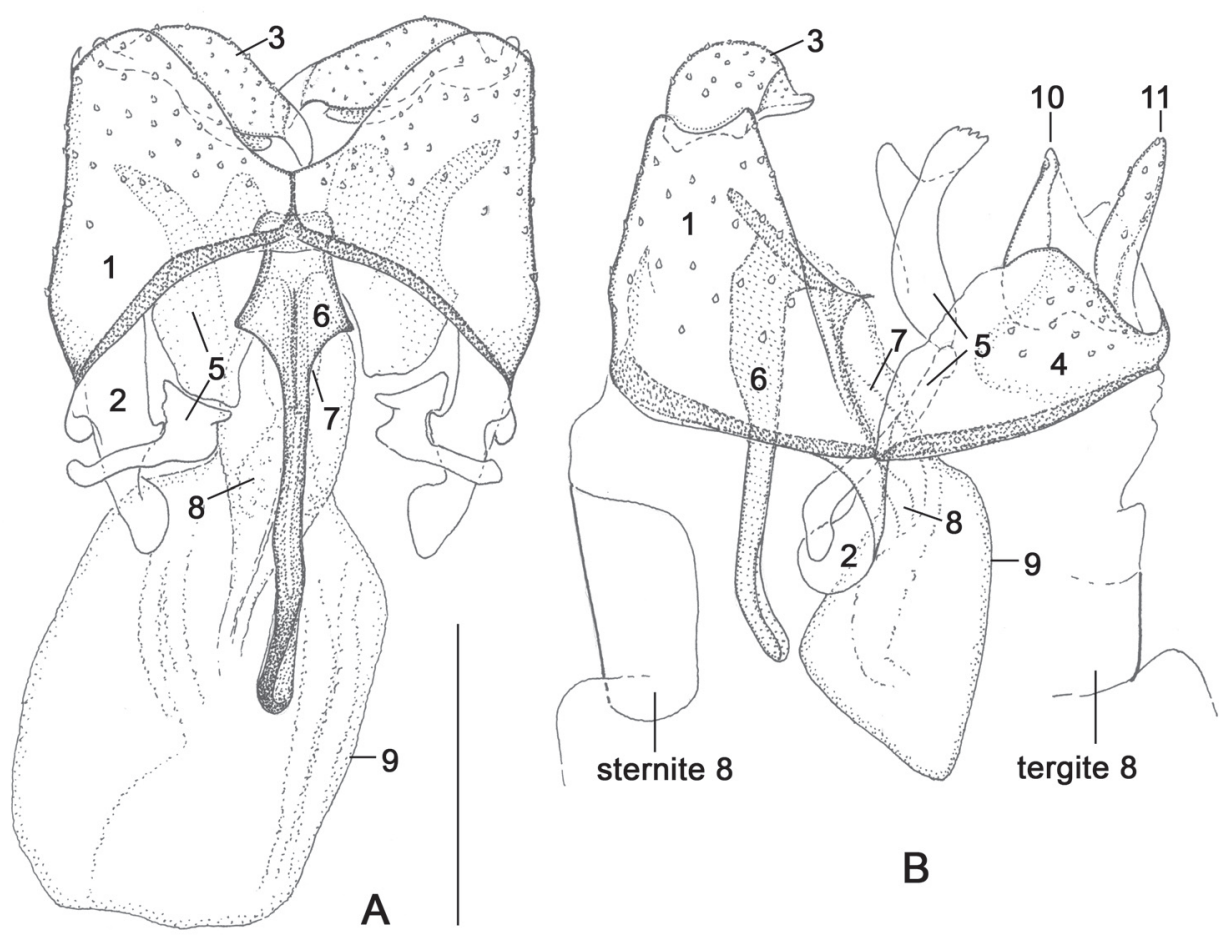

Fig. 1: Colonomyia tasmanica sp. n., paratype males. - A: terminalia, ninth tergite and adjacent structures omitted, ventral view; - B: terminalia, lateral view. 1 = gonocoxite, $2=$ gonocoxal apodeme, 3 = gonostylus, $4=$ ninth tergite, $5=$ paramere, $6=$ ejaculatory apodeme, $7=$ endophallus, $8=$ pubescent bulge, $9=$ sperm sac, $10=$ tenth sternite, $11=$ cercus. Length of scale bar $=0.1 \mathrm{~mm}$.

\section{Terminalia:}

Tergum 9 short, its sclerotized portion consisting of 2 lateral setose lobes connected by narrow asetose portion; basal margin strongly sclerotized (Fig. 1B). Gonocoxites with both ventrobasal margin and longitudinal axis strongly sclerotized; ventral emargination wide and long, i. e. extending beyond halflength (Fig. 1A). Gonostylus with wide basal portion extended dorsomesally into flat, rounded lobe; distal process bare along full length dorsally and half length ventrally; 3 tiny setulae subapically (Figs 1, 2). Ejaculatory apodeme spade-shaped in ventral view (Fig. 1A). Sperm sac very large, slightly sclerotized (Fig. 1). A tubular extension of sperm sac, the endophallus, present dorsad of ejaculatory apodeme; at transition of sperm sac to endophallus is a large, pubescent membranous bulge (Fig. 2). Each of parameres consist of 2 articulating portions; distal portion with lateral lobe slender and apically serrate, and mesal lobe wide and rounded; proximal portion directed anteroventrad and attached to gonocoxal apodeme (Figs 1,2). Sternite 10 subtriangular, densely pubescent and with 2 large setae on distal margin (Fig. 1B). Cerci as long as sternite 10, with setae of various sizes (Fig. 1B).

Female. Body length: 2.0-2.5 mm. Head: Fourth antennal flagellomere 4 times as long as wide.

Legs: Fore basitarsus proximally with no pale setiform sensilla, mid basitarsus with 3, and hind basitarsus with 4-5. 


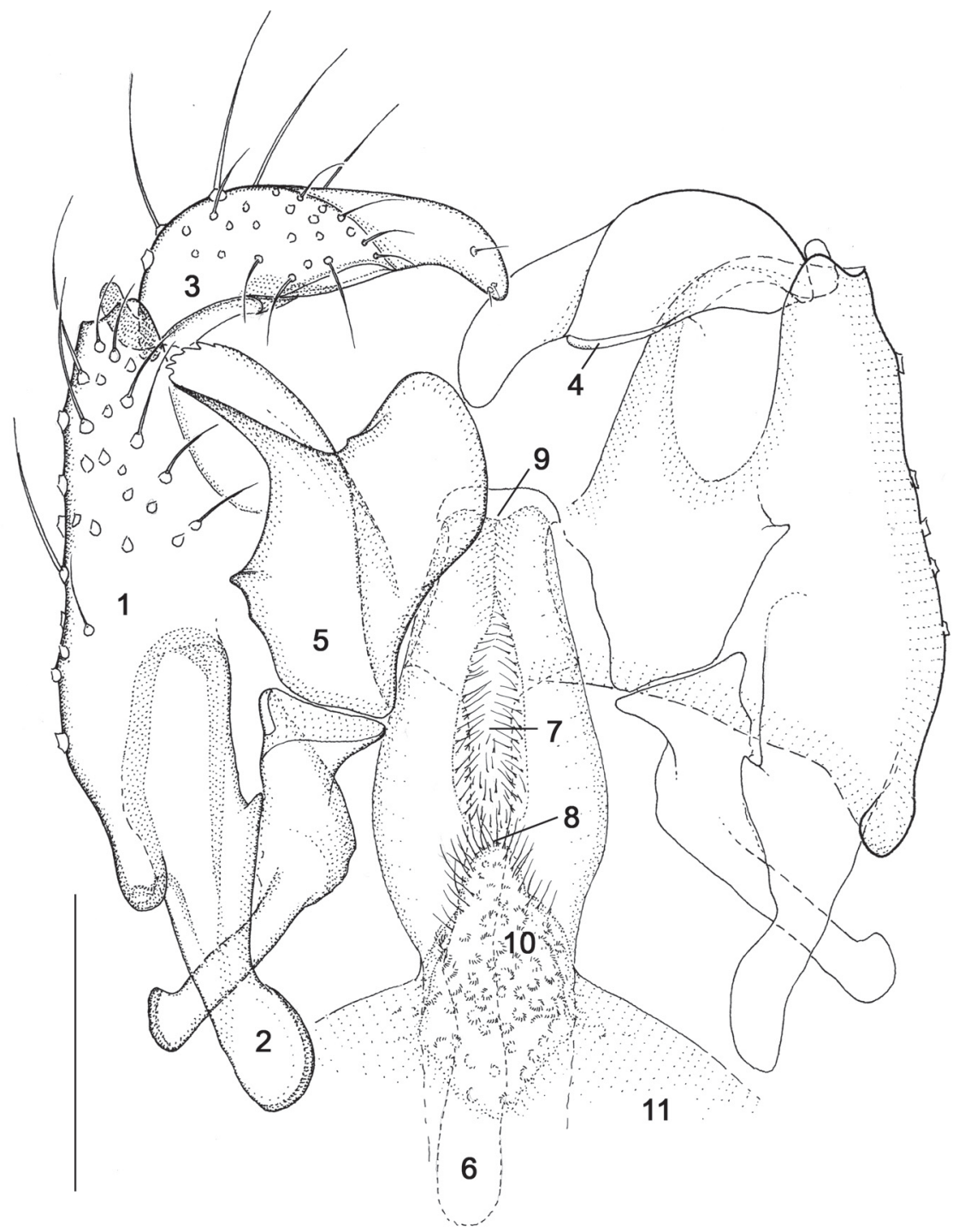

Fig. 2: Colonomyia tasmanica sp. n., paratype male; terminalia, ninth tergite and adjacent structures omitted, dorsal view. 1 = gonocoxite, 2 = gonocoxal apodeme, $3=$ gonostylus, $4=$ dorsomesal lobe of gonostylus, $5=$ paramere, 6 = ejaculatory apodeme, $7=$ endophallus, $8=$ primary gonopore, $9=$ phallotrema, $10=$ pubescent bulge, $11=$ sperm sac. Length of scale bar $=0.05 \mathrm{~mm}$.

\section{Terminalia:}

With modification of segments 8 and 9 as follows. Posterior portion of tergum 8 membranous and bare except a pubescent lobe mesally on posterior margin (Fig. 4A). Sternum 8 with unsclerotized portion anterior of gonocoxal emargination (Fig. 3), and with interior sclerotized brace laterally (Fig. 3A). Surface of tergum 9 bare. Tergite 9 internalized, forming together with gonapophyses moderately sclerotized, complex interior apparatus (Figs 3A, 4A, 5A). Gonapophyses largely 

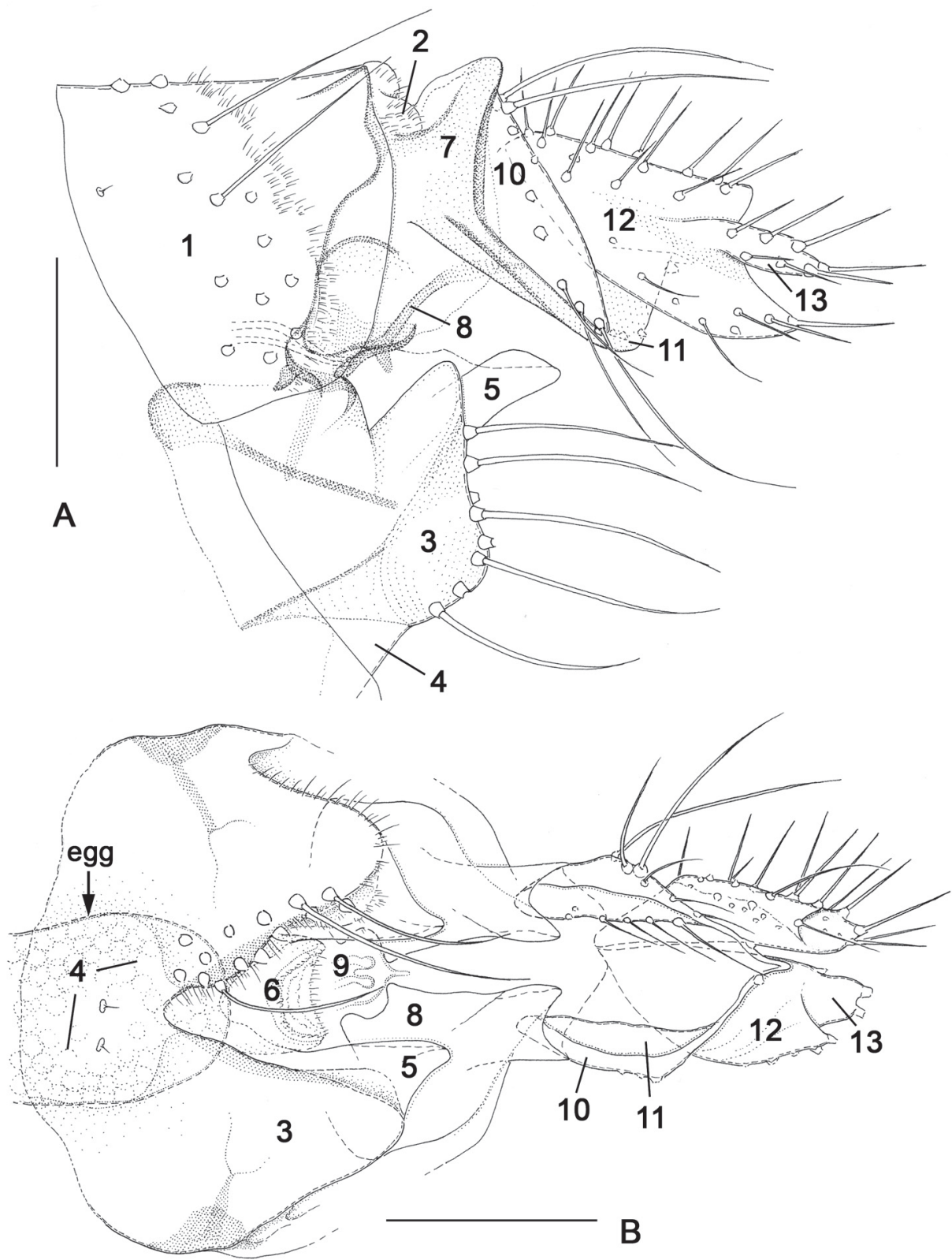

Fig. 3: Colonomyia tasmanica sp. n., paratype females. - A: terminalia, lateral view; - B: terminalia, ventral view. 1 = eighth tergum, with only the distalmost microtrichia indicated, $2=$ pubescent lobe on posterior margin of eighth tergum, 3 = gonocoxite of eighth segment, $4=$ desclerotized portion of eighth sternum, $5=$ gonapophysis of eighth segment, $6=$ labia, $7=$ ninth tergum, $8=$ gonapophysis of ninth segment, $9=$ spermathecal eminence, $10=$ tenth tergite, $11=$ tenth sternite, $12=$ proximal cercus segment, $13=$ distal cercus segment. Length of scale bar $=0.05 \mathrm{~mm}$. 
separated longitudinally; notum membranous, with cone-shaped sclerotized appendage (Fig. 5A). Gonocoxites present as 2 small, pubescent interior lobes (Fig. 5A).

\section{Species comparison:}

Based on features of the male and female terminalia, Colonomyia tasmanica is the sister species of rakelae. Respective mutual characters are mentioned in the keys above, as well as some of the distinguishing characters.

\section{Distribution and phenology:}

The distribution of tasmanica apparently is confined to Tasmania, where its presence is known from four sites distant to one other (see below). At three sites it was found sympatric with albicaulis. Based on the total numbers of specimens found, tasmanica (257) may be regarded as more common than albicaulis (106). Records of tasmanica at Warra are from all months but June and November, with an altitudinal range from 100 to $1100 \mathrm{~m}$ a.s.l. Adults were trapped in both unmanaged and treated forest areas, with up to 42 individuals found in a single sample. At Mt Weld three male specimens were found in a pitfall trap at $1100 \mathrm{~m}$ a.s.l., which is above the tree line.

Etymology: The species epithet refers to Tasmania, where all specimens known of this species are from.

Types: Holotype: Male, Australia, Tasmania, Warra Long Term Ecological Research (LTER) Site, Manuka Road (43.07S, 146.67E), in control area, 1 Aug. 2005, by Malaise trap, R. BAsHFORD (FT\#37051). Paratypes: 2 females, same site but in pre-logging area, 14 April 2000 (FT\#28645); 5 females, same site but in treatment area 1 year post logging, 2 May 2003 (FT\#29026); 4 males, 3 females, same site but in treatment area 1 year post logging, 1 July 2005 (FT\#36775); 5 males, same data as the holotype; 1 female, same site but in control area, 2 April 2007 (FT\#40220); 2 males, Warra LTER Site, Mt Weld (43.07S, 146.67E), $100 \mathrm{~m}$ a.s.l., in mixed forest, 22 Jan. 2002, by Malaise trap, N. Doran \& R. Bashford (FT\#5833).

\section{Further material (in ethanol):}

Tasmania: 151 males, 75 females, Warra LTER Site, Manuka Road and Mt Weld, 24 March 2000-7 Jan. 2008 (52 Malaise and 1 pitfall samples), R. BASHFord, N. Doran, M. \& C. JaschHof; 1 female, Mersey River 4 km S Liena, 30 Dec. 2007, M. Jaschnof; 3 males, 3 females, Lake St. Clair SW shore, 31 Dec. 2007, M. Jaschnof; 1 female, Central Plateau, gravelroad from Road B51 to Little Lake (1000 m a.s.l., 41.57.237S, 146.51.928E), 25 Feb.-4 March 2006, N. Jönsson, T. Malm \& D. Williams.

\section{Colonomyia albicaulis COLLESS, 1963}

(Figs 4B, 5B)

Colless 1963: 305, Hippa \& JaschHof 2004: 345, figs 1-8.

Supplement to the redescription by Hippa \& JAsснноғ (2004):

Male. Head: Maxillary palpus at least in some specimens 5-segmented, with first segment weak and non-setose, and third segment bearing translucent setiform sensilla.

Legs: Fore basitarsus proximally with 2-3 pale setiform sensilla, mid basitarsus with 4-5, and hind basitarsus with 3-5. 

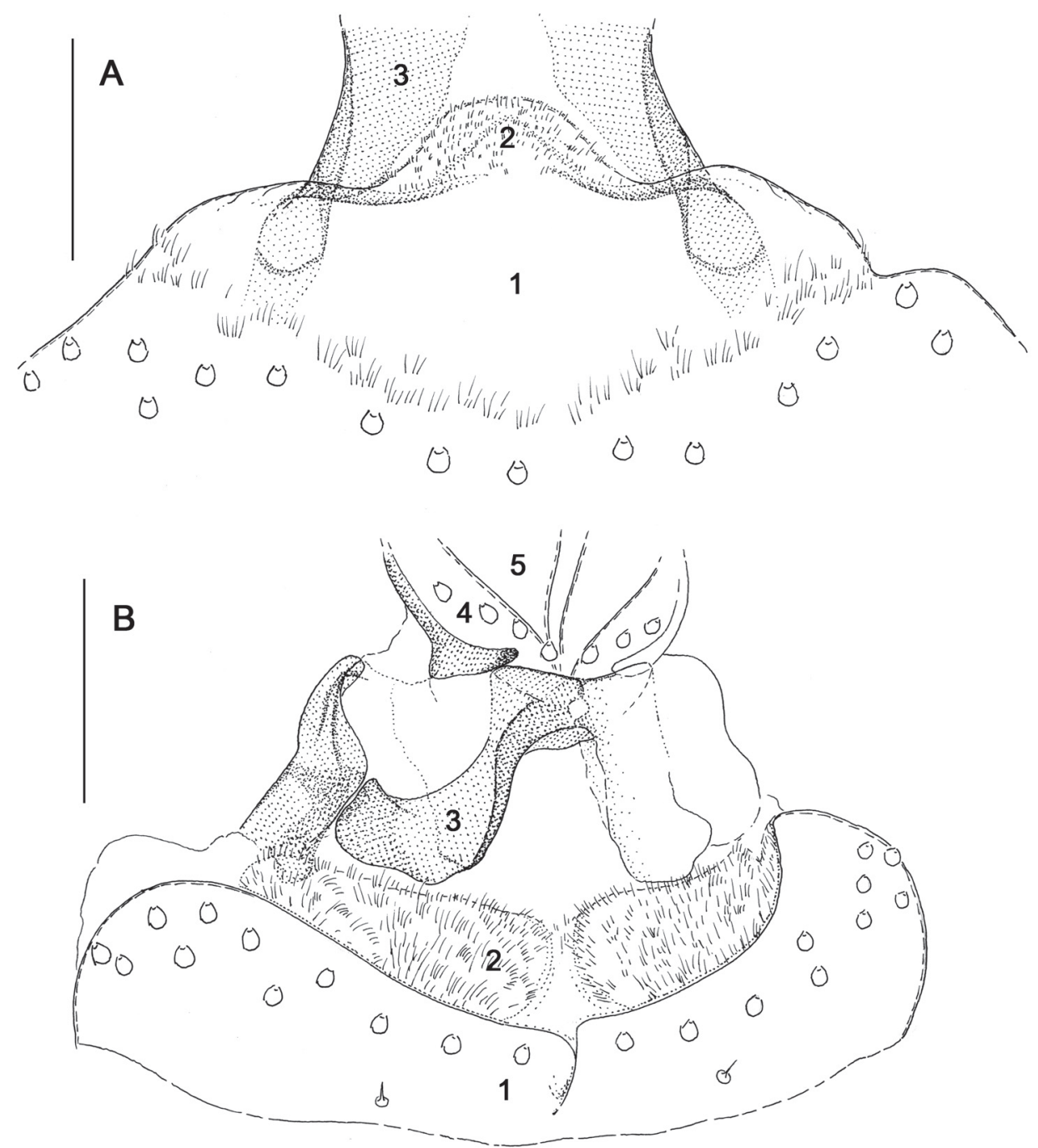

Fig. 4: Anterior portion of female terminalia, dorsal view. - A: Colonomyia tasmanica sp. n. (paratype); - B: Colonomyia albicaulis Colless (specimen from Warra). 1 = eighth tergum, 2 = pubescent lobe(s) on posterior margin of eighth tergum, $3=$ ninth tergite, $4=$ tenth tergite, $5=$ proximal cercus segment. Length of scale bar $=0.05 \mathrm{~mm}$.

\section{Terminalia:}

Head-like extension of ejaculatory apodeme with 1 mesal pair of straight, retractable processes ventrally, 1 lateral pair of widely spread, curved processes dorsally and stiff, subrectangular plate between the process pairs. Sperm sac similar to that of tasmanica but smaller.

\section{Female. Terminalia:}

With modification of segments 8 and 9 as follows. Tergite 8 with 2 wide pubescent lobes on posterior margin (Fig. 4B). Sternum 8 with large unsclerotized portion anterior of gonocoxal emargination, and interior sclerotized brace laterally. Surface of tergum 9 bare. Tergite 9 

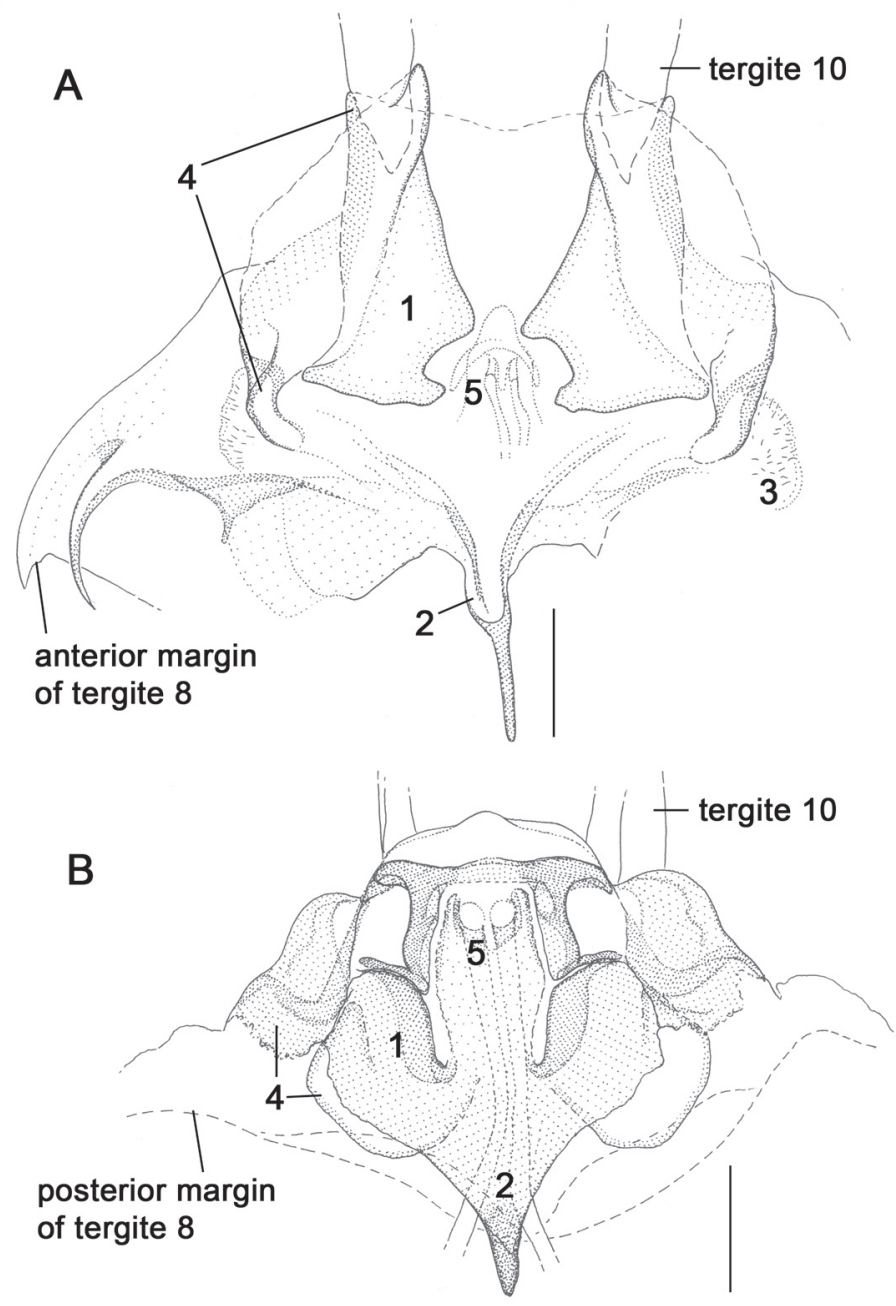

Fig. 5: Dorsal wall of female genital chamber, ventral view. - A: Colonomyia tasmanica sp. n. (paratype); - B: Colonomyia albicaulis Colless (specimen from Warra). 1 = gonapophysis of ninth segment, $2=$ notum, $3=$ gonocoxite of ninth segment, 4 = tergite of ninth segment, $5=$ spermathecal eminence. Length of scale bar $=0.05 \mathrm{~mm}$.

internalized, forming together with gonapophyses strongly sclerotized, complex interior apparatus (Figs 4B, 5B). Gonapophyses merged anteriorly; notum moderately sclerotized, with short coneshaped appendage (Fig. 5B). Gonocoxites not traceable.

\section{Distribution and phenology:}

The distribution of albicaulis in the Australian mainland is southeastern, encompassing the southeasternmost Queensland (unpublished data), New South Wales, Victoria, and Australian Capital Territory. In Tasmania, albicaulis has been found hitherto at five sites distant to one other (including Mt Wellington, cf. Hippa \& Jaschноғ 2004). At Warra findings are from all 
months but June, September and November, and altitudes ranging from 100 to $1100 \mathrm{~m}$ a.s.l. Maximum number is 13 individuals found in a single Malaise sample. Adults were trapped in both unmanaged and treated forest areas. At Mt Weld one male and one female of albicaulis were found at $1100 \mathrm{~m}$ a.s.l. in the same pitfall trap that caught also tasmanica.

\section{Material studied (on slide):}

Tasmania: 8 males, 1 female, Warra LTER Site, Manuka Road, 14 April 2000, R. BASHFord; 1 female, same site but 2 May 2003; 1 male, 1 female, same site but 1 July 2005, 1 male, same site but 1 Aug. 2005; 1 male, same site but 2 April 2007.

\section{Further material (in ethanol):}

Tasmania: 47 males, 37 females, Warra LTER Site, Manuka Road and Mt Weld, 24 March 20007 Jan. 2008 (35 Malaise, 1 pitfall and 1 aspirator samples), R. Bashford, N. Doran, M. \& C. Jaschrof; 4 males, 2 females, Mersey River 4 km S Liena, 30 Dec. 2007, M. Jaschrof; 1 female, Lake St. Clair SW shore, 31 Dec. 2007, M. Jaschноғ; 1 male, Mt Field National Park, near Lake Dobson Road (750 m a.s.l., 42.40.857S, 146.39.367E), 20 Feb.-2 March 2006, N. Jönsson, T. Malm \& D. Williams.

\section{Acknowledgements}

Our study of the sciaroid fauna at Warra LTER Site was supported by a Warra Small Project Grant offered by Forestry Tasmania (FT). FT also allowed us to study their large wet collection of arthropods, provided laboratory facilities during our stay in Hobart, and supported our field work in Warra in December 2007 to January 2008. We remember gratefully the friendly welcome offered to us by the Staff of the FT Head Office in Hobart, Melville Street. Our sincere thanks go especially to Dr Simon Grove, Conservation Biologist with FT, whose interest and support was crucial for our study. We are grateful to the Entomology Department, Naturhistoriska Riksmuseet Stockholm, Sweden, for allowing us to study the Sciaroidea from their 2006 expedition to Tasmania. We thank Dr Raymond J. Gagné, research emeritus with the Systematic Entomology Laboratory, USDA, National Museum of Natural History, Washington, D.C., for reading and commenting on the manuscript.

\section{Literature}

Amorim, D. S. \& Rindal, E. 2007: Phylogeny of the Mycetophiliformia, with proposal of the subfamilies Heterotrichinae, Ohakuneinae, and Chiletrichinae for the Rangomaramidae (Diptera, Bibionomorpha). - Zootaxa, Auckland 1535: 1-92.

Bashford, R.; Taylor, R.; Driessen, M.; Doran, N. \& Richardson, A. 2001: Research on invertebrate assemblages at the Warra LTER Site. - Tasforests, Hobart 13 (1): 109-118.

Brown, M. J.; Elliott, H. J. \& Hickey, J. E. 2001: An overview of the Warra Long-Term Ecological Research Site. - Tasforests, Hobart 13 (1): 1-8.

Colless, D. H. 1963: New species of Ohakunea Edwards and a related new genus with notes on the relationships of Heterotricha Loew (Diptera). - Proceedings of the Linnean Society of New South Wales, Sydney 87: 303-308.

Freeman, P. 1951: Diptera of Patagonia and South Chile. Part III - Mycetophilidae. - London: British Museum (Natural History): 138 pp. + XLIX plts.

Hippa, H. \& Jaschiof, M. 2004: A re-examination of Colonomyia Colless (Diptera, Sciaroidea), with the description of two new species. - Insects Systematics and Evolution, Copenhagen 35: 335-352.

Hippa, H. \& VilkamaA, P. 2005: The genus Sciarotricha gen. n. (Sciaridae) and the phylogeny of recent and fossil Sciaroidea (Diptera). - Insect Systematics and Evolution, Copenhagen 36: 121-144. 
Hippa, H. \& Vilkamaa, P. 2006: Phylogeny of the Sciaroidea (Diptera): the implication of additional taxa and character data. - Zootaxa, Auckland 1132: 63-68.

Jaschrof, M. 2006: Rogambara and Cabamofa, two new genera of enigmatic sciaroids from Costa Rica (Insecta: Diptera: Sciaroidea). - Bonner zoologische Beiträge, Bonn 53 (3/4) (2004): 323-332.

Jaschiof, M. \& Hippa, H. 2003: Sciaroid but not sciarid: a review of the genus Ohakunea Tonnoir \& EDWARDS, with the description of two new species (Insecta: Diptera: Bibionomorpha). - Entomologische Abhandlungen, Dresden 60: 23-44.

Jones, D. M.; Wapstra, H.; Tonelli, P. \& Harris, S. 1999: The Orchids of Tasmania. - Carlton South, Victoria: Melbourne University Press: 408 pp.

Matile, L. \& Duret, J. P. 1994: Le genre Colonomyia Colless découvert en région néotropicale [Diptera, Mycetophiloidea]. - Revue française d'Entomologie (N.S.), Paris 16 (4): 143-147.

Semmens, T. D.; McQuillan, P. B. \& Hayhurst, G. 1992: Catalogue of the Insects of Tasmania. - Hobart: Department of Primary Industry Tasmania: $104 \mathrm{pp}$.

Sinclair, B. J. 2000: Morphology and terminology of Diptera male terminalia: 53-74. - In: PApp, L. \& Darvas, B. 2000 (eds): Contributions to a Manual of Palaearctic Diptera (with special reference to flies of economic importance). Volume 1. - Budapest: Science Herald.

SøLI, G. E. E. 1997: The adult morphology of Mycetophilidae (s. str.), with a tentative phylogeny of the family (Diptera, Sciaroidea). - Entomologica Scandinavica Supplement, Lund 50: 5-55.

Søli, G. E. E.; Vockeroth, J. R. \& Matile, L. 2000: A.4. Families of Sciaroidea: 49-92. - In: Papp, L. $\&$ Darvas, B. (eds): Contributions to a Manual of Palaearctic Diptera (with special reference to flies of economic importance). Appendix. - Budapest: Science Herald.

Tonnolr, A. L. \& Edwards, F. W. 1927: New Zealand fungus gnats (Diptera, Mycetophilidae). Transactions of the New Zealand Institute, Wellington 57: 747-878.

WARRA POLICY COMMITTEE \& RESEARCH MANAGEMENT group (without year): Warra Long Term Ecological Research. Available from: http://www.warra.com.au (accessed 5 April 2008).

\section{Authors' address:}

Dr. Mathias JaschhoF

Deutsches Entomologisches Institut (DEI)

Leibniz-Zentrum für Agrarlandschaftsforschung (ZALF)

Eberswalder Straße 84

15374 Müncheberg

Germany

e-mail: mjaschhof@yahoo.de
Subject editor:

Catrin JaschHoF

Thälmann-Ring 64

17489 Greifswald

Germany 